\title{
Problematika Membaca Teks Arab bagi Siswa Madrasah
}

\author{
Nur Khikmah \\ Universitas Islam Negeri Walisongo Semarang \\ Corresponding author: nurkhikmah@walisongo.ac.id
}

\begin{abstract}
Learning to read the text of the Qur'an and hadith at the initial level is to sound the letters of the Qur'an and the hadith itself. Learning to read the Qur'an means learning to pronounce written symbols (letters). The Qur'an and hadith are revealed in Arabic and become a foreign language in learning. Especially in reading the Qur'an, Allah has set rules in reading the Qur'an such as laws and rules. This study aims to describe the problems experienced by students in reading the texts of the Qur'an and hadith. This study uses a qualitative approach with descriptive analytical methods and data collection techniques are observations. The subjects of this study were grade 3 students of MI Walisongo Semarang, totaling 45 people consisting of 6 men and 39 women. The results of the study explain the problem of reading the Qur'anic text and hadith, including: pronunciation of the sounds of the letters hijaiyah (makhorijul letters), short length of charity, and the law of reading (tajwid). And in terms of the environment, namely: students lack focus on learning materials, teacher teaching skills, lack of interest and activities of students in learning to read the Qur'an and hadith, lack of time, facilities and infrastructure for student learning, both at school and at home, and not supporting the community environment.
\end{abstract}

Pembelajaran membaca teks Al-Qur'an dan hadis pada tingkat awal adalah dengan membunyikan huruf-huruf Al-Qur'an dan hadis itu sendiri. Belajar membaca Al-Qur'an artinya belajar mengucapkan lambang-lambang bunyi (huruf) tertulis. Al-Qur'an dan hadis diturunkan dengan bahasa Arab dan menjadi bahasa asing dalam pembelajaran. Khususnya dalam membaca Al-Qur'an, Allah

ISSN 2622-6146 (e) 2622-6138 (p)

(C) 2019 Alsina : Journal of Arabic Studies

http://journal.walisongo.ac.id/index.php/alsina 
telah menetapkan aturan-aturan dalam membaca Al-Qur'an seperti hukum dan kaidah-kaidahnya. Penelitian ini bertujuan untuk mendeskripsikan problematika yang dialami peserta didik dalam membaca teks Al Qur'an dan hadis. Penelitian ini menggunakan pendekatan kualitatif dengan metode deskriptif analitis dan teknik pengumpulan data adalah observasi. Subjek penelitian ini peserta didik kelas 3 MI Walisongo Semarang yang berjumlah 45 orang terdiri dari 6 laki-laki dan 39 perempuan. Hasil penelitian menjelaskan problematika membaca teks Al Qur'an dan hadis, meliputi: pelafalan bunyi-bunyi huruf hijaiyah (makhorijul huruf), panjang pendek harakat, dan hukum bacaan (tajwid). Serta dari segi lingkungan, yaitu: siswa kurang fokus terhadap materi pembelajaran, keterampilan mengajar guru, kurangnya minat dan aktivitas siswa dalam belajar membaca al-Qur'an dan hadis, kurangnya waktu, sarana dan prasarana untuk belajar siswa, baik di sekolah maupun di rumah, dan kurang mendukungnya lingkungan masyarakat.

Keywords: madrasah; problematika membaca; teks Arab.

\section{Pendahuluan}

Rasulullah saw. telah mewariskan dua pusaka yaitu AlQur'an dan sunnah yang barang siapa memegang teguh keduanya maka kita tidak akan tersesat. Al-Qur'an merupakan sumber utama agama Islam sedangkan hadis atau sunnah adalah sumber kedua agama Islam. Al-Qur'an mengandung enam isi pokok kandungan yaitu: akidah, ibadah dan muamalah, akhlak, hukum, sejarah atau kisah umat masa lalu dan dasardasar ilmu pengetahuan dan teknologi. Sedangkan hadis memiliki fungsi: sebagai penegas Al-Qur'an, sebagai penjelas aturan-aturan dalam Al-Qur'an, dan sebagai pembuat hukum baru yang tidak ada dalam Al-Qur'an. Mengingat pentingnya pembelajaran Al-Qur'an, Rasulullah saw. Menganjurkan pembelajaran membaca Al-Qur'an dimulai sejak masa kanak-kanak karena pada masa itu terkandung potensi belajar yang sangat kuat dan besar. Anak akan sangat peka menangkap 
sesuatu yang diperintahkan dan diajarkan sehingga mudah menerima pelajaran-pelajaran yang diberikan.

Pembelajaran membaca teks Al-Qur'an dan hadis pada tingkat awal adalah dengan membunyikan huruf-huruf AlQur'an dan hadis itu sendiri. Al-Qur'an dan hadis diturunkan dengan bahasa Arab dan menjadi bahasa asing dalam pembelajaran. Oleh karena itu, membaca keduanya tidaklah sama dengan membaca huruf-huruf abjad. Khususnya dalam membaca Al-Qur'an, Allah telah menetapkan aturan-aturan dalam membaca Al-Qur'an seperti hukum dan kaidah-kaidahnya. Aturan-aturan tersebut wajib hukumnya untuk diamalkan ketika membaca Al-Qur'an karena apabila salah dalam menerapkannya dapat membuat perbedaan makna dan arti kata dalam Al-Qur'an. Belajar membaca Al-Qur'an artinya belajar mengucapkan lambang-lambang bunyi (huruf) tertulis. Walaupun kegiatan ini cukup sederhana, tetapi bagi peserta didik pemula merupakan kegiatan yang cukup kompleks, karena harus melibatkan berbagai hal, yaitu penglihatan, pendengaran, pengucapan di samping akal pikiran. Kedua hal terakhir ini bekerja secara mekanik dan simultan untuk melahirkan perilaku membaca. Ditambah lagi materi yang dibaca adalah rangkaian kata-kata Arab yang banyak berbeda sistem bunyi dan penulisannya dengan yang mereka kenal dalam bahasa ibu dan bahasa Indonesia. ${ }^{1}$

Problematika yang terjadi pada siswa kelas 3 tentang teks Al-Qur'an dan hadis adalah pada pelafalan bunyi-bunyi huruf serta kaidah-kaidah bacaan yang masih kurang dipahami siswa yang mengakibatkan pembacaan teks tersebut masih banyak kekurangan.

\section{Landasan Teori}

1 Depag RI. 1997. Metode-metode Membaca Al-Qur'an di Sekolah Umum. Jakarta: Dirjen Pembinaan Kelembagaan Agama Islam. 24. 


\section{Peserta Didik}

Menurut Hurlock peserta didik adalah makhluk individu yang mempunyai kepribadian dengan ciri-ciri yang khas yang sesuai dengan pertumbuhan dan perkembangannya. Menurut pasal 1 ayat 4 UU RI No. 20 Tahun 2003 tentang sistem pendidikan nasional, peserta didik adalah anggota masyarakat yang berusaha mengembangkan dirinya melalui proses pendidikan pada jalur jenjang dan jenis pendidikan tertentu. Dalam paradigma pendidikan Islam, peserta didik merupakan orang yang belum dewasa dan memiliki sejumlah potensi (kemampuan) dasar yang masih perlu dikembangkan. ${ }^{2}$

Secara etimologi peserta didik dalam bahasa arab disebut dengan tilmidz jamaknya adalah talamidz, yang artinya adalah "murid", maksudnya adalah "orang-orang yang mengingini pendidikan". Dalam bahasa arab juga dikenal dengan istilah thalib, jamaknya adalah thullab, yang artinya adalah "mencari" maksudnya adalah orang-orang yang mencari ilmu. ${ }^{3}$

Peserta didik dengan keunikannya memiliki ciri-ciri sendiri diantaranya adalah: ${ }^{4}$

a. Peserta didik dalam keadaan sedang berdaya, maksudnya ia dalam keadaan berdaya untuk menggunakan kemampuan, kemauan dan sebagainya.

b. Mempunyai keinginan untuk berkembang ke arah dewasa.

c. Peserta didik mempunyai latar belakang yang berbeda.

d. Peserta didik melakukan penjelajahan alam sekitarnya dengan potensi-potensi dasar yang dimiliki secara individu.

2 Agustina Nora. 2018. Perkembangan Peserta Didik. Yogyakarta: Deepublish. 13.

${ }^{3}$ M. Indra Saputra. 2015. Hakekat Pendidik dan Peserta Didik dalam Pendidikan Islam. At-Tadzkiyyah: Jurnal Pendidikan Islam 6 (2): 243.

${ }^{4}$ M. Indra Saputra. 2015. Hakekat Pendidik dan Peserta Didik dalam Pendidikan Islam. At-Tadzkiyyah: Jurnal Pendidikan Islam 6 (2): 245. 
Selain ciri-ciri peserta didik juga memiliki karakter, yaitu: ${ }^{5}$

a. Peserta didik bukan miniatur orang dewasa, ia mempunyai dunia sendiri, sehingga metode belajar mengajar tidak boleh dilaksanakan dengan orang dewasa. Orang dewasa tidak patut mengeksploitasi dunia peserta didik, dengan mematuhi segala aturan dan keinginannya, sehingga peserta didik kehilangan dunianya.

b. Peserta didik memiliki kebutuhan dan menuntut untuk pemenuhan kebutuhan itu semaksimal mungkin. Terdapat lima hierarki kebutuhan yang dikelompokkan dalam dua kategori, yaitu: (1) kebutuhan-kebutuhan tahap dasar (basic needs) yang meliputi kebutuhan fisik, rasa aman dan terjamin, cinta dan ikut memiliki (sosial), dan harga diri; dan (2) metakebutuhan-metakebutuhan (meta needs), meliputi apa saja yang terkandung dalam aktualisasi diri, seperti keadilan, kebaikan, keindahan, keteraturan, kesatuan, dan lain sebagainya. Sekalipun demikian, masih ada kebutuhan lain yang tidak terjangkau kelima hierarki kebutuhan itu, yaitu kebutuhan akan transendensi kepada Tuhan. Individu yang melakukan ibadah sesungguhnya tidak dapat dijelaskan dengan kelima hierarki kebutuhan tersebut, sebab akhir dari aktivitasnya hanyalah keikhlasan dan ridha dari Allah SWT.

c. Peserta didik memiliki perbedaan antara individu dengan individu yang lain, baik perbedaan yang disebabkan dari faktor endogen (fitrah) maupun eksogen (lingkungan) yang meliputi segi jasmani, intelegensi, sosial, bakat, minat, dan lingkungan yang mempengaruhinya. Peserta didik dipandang sebagai kesatuan sistem manusia. Sesuai dengan hakikat manusia, peserta didik sebagai makhluk monopluralis, maka pribadi peserta didik walaupun

${ }^{5}$ M. Ramli. Hakikat Pendidik dan Peserta Didik. Tarbiyah Islamiyah: Jurnal: Jurnal Ilmiah Pendidikan Agama Islam 5 (1): 79-80. 
terdiri dari banyak segi, merupakan satu kesatuan jiwa raga (cipta, rasa dan karsa).

d. Peserta didik merupakan subjek dan objek sekaligus dalam pendidikan yang dimungkinkan dapat aktif, kreatif, serta produktif. Setiap peserta didik memiliki aktivitas sendiri (swadaya) dan kreatifitas sendiri (daya cipta), sehingga dalam pendidikan tidak hanya memandang anak sebagai objek pasif yang bisanya hanya menerima, mendengarkan saja.

e. Peserta didik mengikuti periode-periode perkembangan tertentu mempunyai pola perkembangan serta tempo dan iramanya. Implikasi dalam pendidikan adalah bagaimana proses pendidikan itu dapat disesuaikan dengan pola dan tempo, serta irama perkembangan peserta didik. Kadar kemampuan peserta didik sangat ditentukan oleh usia dan periode perkembangannya, karena usia itu bisa menentukan tingkat pengetahuan, intelektual, emosi, bakat, minat peserta didik, baik dilihat dari dimensi biologis, psikologis, maupun dedaktis.

Dalam buku filsafat pendidikan Islam yang ditulis oleh Hasan Basri, dalam perspektif filsafat pendidikan Islam, hakikat peserta didik terdiri dari beberapa macam: ${ }^{6}$

a. Peserta didik adalah darah daging sendiri, orang tua adalah pendidik bagi anak-anaknya maka semua keturunannya menjadi anak didiknya di dalam keluarga.

b. Peserta didik adalah semua anak yang berada di bawah bimbingan pendidik di lembaga pendidikan formal maupun non formal, seperti di sekolah, di pondok pesantren, tempat pelatihan, sekolah keterampilan, pengajian anakanak, majlis ta'lim, dan sejenisnya.

${ }^{6}$ M. Indra Saputra. 2015. Hakekat Pendidik dan Peserta Didik dalam Pendidikan Islam. At-Tadzkiyyah: Jurnal Pendidikan Islam 6 (2): 245. 
Sebagai orang yang mencari ilmu, peserta didik memiliki kewajiban yang harus dilakukan. Kewajiban peserta didik tidak terlepas dari hadis Rasulullah yang menegaskan bahwa "menuntut ilmu itu wajib atas kaum muslim laki-laki dan kaum muslim perempuan." Pembelajaran dapat dilakukan dengan berbagai cara, seperti membaca, menulis, mendengar, melihat, berpikir, menelaah, berdiskusi, berdialog, meneladani, mengambil ibrah, melatih atau membiasakan diri, dan masih banyak lagi yang harus dilakukan peserta didik dalam proses pembelajaran. Selain hal-hal tersebut berkenaan dengan tanggungjawab utama peserta didik adalah memanfaatkan apa yang telah dimiliki (potensi) untuk dipelihara dan digunakan sebagaimana mestinya.

\section{Membaca}

Menurut Hodgson membaca merupakan suatu proses yang menuntut agar kelompok kata yang merupakan suatu satu kesatuan akan terlihat dalam satu pandangan sekitar, dan agar makna kata-kata secara individual akan dapat diketahui. Kalau hal ini tidak dapat terpenuhi, maka peran yang tersurat atau tersirat tidak akan tertangkap atau dipahami dan prosedur membaca ini tidak terlaksana dengan baik. Griffith, mendefiniskan, pada hakikatnya, aktivitas membaca terdiri dari dua bagian; membaca sebagai proses dan membaca sebagai produk. Membaca sebagai proses mengacu pada aktivitas fisik dan mental. ${ }^{7}$

Macam-macam membaca ada 4 , yaitu: ${ }^{8}$

${ }^{7}$ Roichatul Jannah dan Siti Nur Kholifah. 2016. Peningkatan Keterampilan Membaca Tulisan Arab dengan Menggunakan Strategi Pembelajaran Aktif Tipe Sort Card bagi Peserta didik Kelas II MI Banu Hasyim Sidoarjo. J. PTK-PAI: Penelitian Tindakan Kelas-Pendidikan Agama Islam 7 (2): 289.

${ }^{8}$ Roichatul Jannah dan Siti Nur Kholifah. 2016. Peningkatan Keterampilan Membaca Tulisan Arab dengan Menggunakan Strategi Pembelajaran Aktif Tipe Sort Card bagi Peserta didik Kelas II MI Banu Hasyim 
a. Membaca cepat, peserta didik dapat termotivasi untuk suka membaca, mengatasi regresi (mengulang bacaan yang sudah dibaca), menggunakan pandangan perifera (baca sistem loncat), menggunakan suatu petunjuk sebagai penentu kecepatan, mengkondisikan situasi, dan mampu mengkonsolidasi.

b. Membaca intensif, peserta didik dapat memahami bacaan secara intensif, tanpa bersuara, dan tuntas. peserta didik memahami bacaan tertentu tanpa harus berkomat-kamit, sangat tekun dan analitis, kemudian dapat menjawab pertanyaan bacaan sesulit apapun.

c. Membaca kritis, peserta didik memberikan komentar yang mendetail mengenai bacaan yang mereka baca. Peserta didik disuruh membaca sebuah bacaan dan dalam waktu tertentu peserta didik disuruh memberikan kritikan mengenai isi bacaan tersebut.

d. Membaca nyaring, membaca dengan melafalkan atau menyuarakan simbol-simbol tertulis berupa kata-kata atau kalimat yang dibaca. Latihan membaca ini lebih cocok diberikan kepada pelajar tingkat pemula.

Menurut Saleh Abbas, membaca pada hakikatnya adalah suatu aktivitas untuk menangkap informasi bacaan baik yang tersurat maupun yang tersirat dalam bentuk pemahaman bacaan secara literal, inferensial, evaluatif, dan kreatif dengan memanfaatkan pengalaman pembaca. ${ }^{9}$

Membaca merupakan suatu kegiatan yang bersifat kompleks karena kegiatan ini karena melibatkan kemampuan dalam mengingat simbol-simbol grafis yang berbentuk huruf, mengingat bunyi dari simbol-simbol tersebut dan menulis

Sidoarjo. J. PTK-PAI: Penelitian Tindakan Kelas-Pendidikan Agama Islam 7 (2): 290 . 
simbol-simbol grafis dalam rangkaian kata dan kalimat yang mengandung makna. ${ }^{10}$

Berdasarkan firman Allah Swt, membaca Al-Qur'an merupakan kewajiban, karena Allah SWT yang memerintahkan. Wahyu yang pertama turun adalah perintah membaca. Allah SWT berfirman :

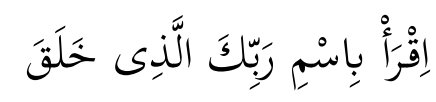

"Bacalah dengan (menyebut) nama Tuhanmu yang menciptakan"11

Wahyu pertama yang disampaikan Allah Swt. kepada Nabi Muhammad Saw. melalui perantara malaikat Jibril adalah perintah membaca karena dengan membaca, Allah Swt. mengajarkan tentang ilmu pengetahuan. Dengan demikian maka kegiatan membaca merupakan kegiatan yang sangat diperlukan oleh siapapun yang ingin maju dan meningkatkan potensi diri. Oleh sebab itu, peran guru mengajarkan membaca di sekolah sangat penting.

Membaca sebagai suatu keterampilan, memandang hakikat membaca itu sebagai suatu proses atau kegiatan yang menerapkan seperangkat keterampilan dalam mengolah halhal yang dibaca untuk menangkap makna. Membaca merupakan proses merekonstruksi informasi yang terdapat dalam bacaan atau sebagai suatu upaya untuk mengolah informasi dengan menggunakan pengalaman atau kemampuan pembaca dan kompetensi bahasa yang dimilikinya secara kritis. ${ }^{12}$

10 Martini, Jamaris. 2014. Kesulitan Belajar Perspekif, Assessment, dan Penanggulanganya Bagi Anak Usia Dini dan Usai Sekolah. Bogor: Ghalia Indonesia. 133.

${ }^{11}$ Departemen Agama Republik Indonesia. 2012. Al-Qur'an dan Terjemahannya. Bandung: PT. Sinergi Pustaka Indonesia. 904.

12 Tim Penulis. Metodik Khusus Pengajaran Agama Islam. Jakarta : Direktorat jenderal Pembinaan Kelembagaan Agama Islam. 69. 
Al-Qur'an menurut bahasa artinya "bacaan", selanjutnya batasan umum Al-Qur'an artinya wahyu Allah yang kekal dan dijaga-Nya, Al-Qur'an merupakan firman Allah yang diwahyukan kepada Nabi Muhammad SAW, melalui perantaraan malaikat Jibril untuk disampaikan kepada seluruh umat manusia di muka bumi. Al-Qur'an berisi kandungan yang memuat segala aturan serta semua aspek kehidupan manusia, ringkasnya Al-Qur'an adalah pedoman hidup bagi manusia yang mengaku sebagai muslim. Dari uraian tersebut menimbulkan suatu kewajiban bagi umat Islam untuk membacanya, menghafal, memahami maknanya, serta mengamalkan kandungan Al-Qur'an. Kewajiban yang pertama adalah membaca, termasuk belajar membaca. Kemampuan membaca Al-Qur'an merupakan kewajiban awal terhadap pedoman hidup, karena tidak mungkin bisa memahami tanpa bisa membaca. Kewajiban belajar Al-Qur'an menimbulkan kewajiban lain bagi guru dan orang tua yaitu mengajarkan Al-Qur'an baik segi membaca atau kandungan isinya.

Membaca Al-Qur'an adalah melafalkan huruf-huruf menjadi kata dan kalimat dengan pengucapan yang jelas berbeda huruf demi huruf dalam satu kalimat atau satu ayat. ${ }^{13}$ Dari uraian di atas memberikan makna pada kita beberapa hal yang membedakan pengertian membaca Al-Qur'an dengan membaca bacaan lainnya. Bahwa membaca Al-Qur'an merupakan perintah Allah disertai dengan maknanya, agar manusia memikirkannya sebagai bentuk ketaatan manusia pada Sang Maha Pencipta, sehingga manusia bisa berdialog dengan hari akhir sebagai konsekuensi amal perbuatan di muka bumi. Bila kita simpulkan maka membaca Al-Qur'an merupakan amal

13 Bulaeng. 2016. Peningkatan Kemampuan Membaca Al-Qur'an Dengan Tartil Melalui Metode Iqra Pada Peserta Didik Kelas V Di SD Inpres Tinggimae Kecamatan Somba Opu Kabupaten Gowa. Skripsi. Fakultas Tarbiyah dan Keguruan, Universitas Islam Negeri Alauddin Makassar. 12. 
ibadah yang memiliki nilai amat tinggi, sehubungan yang dibaca adalah bacaan yang mengandung nilai-nilai luhur dari agama, hal tersebut dimungkinkan apabila membaca AlQur'an bukan semata membaca, tetapi memahami maknanya, memikirkannya serta berusaha mengamalkannya. Yang dimaksud dengan membaca Al-Qur'an pada kajian teori kali ini adalah pembelajaran membaca, melafalkan bacaan diperdengarkan dan harus terdengar sehingga jelas bacaan huruf serta kalimat yang benar sesuai kaidah makhraj dan tajwid, bukan membaca tanpa terdengar atau membaca Al-Qur'an dalam hati, tidak ada konsep membaca Al-Qur'an dalam hati karena tidak akan kedengaran makhraj dan tajwidnya.

Metode membaca nyaring Al-Qur'an yaitu: ${ }^{14}$

a. Murottal yaitu membaca Al-Qur'an satu atau beberapa surat dengan bacaan yang bagus tajwid dan makhrajnya, tanpa lagu-lagu khusus, biasanya untuk membacakan lebih dari satu surat.

b. Qira'at sering juga disebut seni baca Al-Qur'an yaitu membaca Al-Qur'an dengan kaidah makhraj dan tajwid sebagai aturan baca yang wajib terdengar dengan baik, disertai lagu-lagu khusus bacaan Al-Qur'an, seperti lagu bayyati, shoba, hijaz, rhast, sikhah, nahawan, jiharkhah dengan tangga nada rendah, sedang, tinggi dan sangat tinggi.

\section{Metode}

Metode penelitian ini adalah metode penelitian kualitatif. Menurut Bogdan dan Taylor metode penelitian kualitatif sebagai prosedur penelitian yang menghasilkan data deskriptif

14 Bulaeng. 2016. Peningkatan Kemampuan Membaca Al-Qur'an Dengan Tartil Melalui Metode Iqra Pada Peserta Didik Kelas V Di SD Inpres Tinggimae Kecamatan Somba Opu Kabupaten Gowa. Skripsi. Fakultas Tarbiyah dan Keguruan, Universitas Islam Negeri Alauddin Makassar. 13. 
berupa kata-kata tertulis atau lisan cari orang-orang atau perilaku yang dapat diamati. Penelitian ini diajukan untuk menganalisis dan mengungkapkan kejadian problematika membaca teks Al-Quran dan hadis bagi siswa MI. Dalam mengumpulkan, mengungkapkan berbagai masalah dan tujuan yang hendak dicapai maka, penelitian ini dilakukan dengan pendekatan studi deskriptif analitis. Menurut Sugiyono penelitian kualitatif deskriptif adalah metode penelitian yang dilandaskan pada filsafat postpositivisme yang biasanya digunakan untuk meneliti pada kondisi objektif alamiah dimana peneliti berperan sebagai instrumen kunci. Menurut Winamo, ${ }^{15}$ pada penelitian ini peneliti menjadi alat peneliti utama yang mana melakukan penelitian langsung dan aktif mengumpulkan berbagai materi atau bahan yang berkaitan dengan penelitian. Guna menemukan hasil penelitian maka peneliti menempuh beberapa langkah yaitu pengumpulan data, pengolahan data, penyusunan laporan serta penarikan kesimpulan.

Penelitian ini dilaksanakan di MI Walisongo Ngaliyan kelas 3 dengan siswa berjumlah 45 orang yang terdiri dari 6 laki-laki dan 39 perempuan. Pertimbangan pemilihan kelas 3 sebagai subjek dan sumber data penelitian karena di kelas tersebut ditemukan permasalahan-permasalahan yang terjadi saat kegiatan membaca dilaksanakan. Objek penelitian tindakan kelas ini adalah pembacaan teks Al-Qur'an dan hadis pada mata pelajaran Fikih, al Qur'an hadis, Aqidah Akhlak, SKI dan Bahasa Arab.

Teknik dan instrumen merupakan cara dan alat yang digunakan dalam mengumpulkan data sebagai salah satu bagian penting dalam penelitian. Teknik pengumpulan data

${ }^{15}$ Agustinus, Ufie. 2013. Kearifan Lokal (Local Wisdom) Budaya Ain Ni Ain Masyarakat Kei sebagai Sumber Belajar Sejarah Lokal untuk Memperkokoh Kohesi Sosial Siswa. Thesis. Program Studi Pendidikan Sejarah, Universitas Pendidikan Indonesia. 39-40. 
penelitian yang terkait dengan pengumpulan data yang digunakan adalah observasi. Observasi atau pengamatan merupakan suatu teknik atau cara mengumpulkan data dengan jalan mengadakan pengamatan terhadap kegiatan yang sedang berlangsung. Metode observasi ini digunakan untuk mendapatkan data secara langsung terhadap model pembelajaran Fikih, al Qur'an hadis, Aqidah Akhlak, SKI dan Bahasa Arab di MI Walisongo Ngaliyan.

Setelah data terkumpul, langkah selanjutnya adalah mengolah, menganalisa serta mengambil kesimpulan dari data yang terkumpul. Tujuan analisa data dalam penelitian itu adalah untuk memfokuskan dan membatasi penemuanpenemuan sehingga menjadi data yang teratur dan tersusun secara rapi dan berarti. Metode yang digunakan dalam menganalisis data yaitu bersifat kualitatif yang digambarkan dengan kata-kata atau kalimat yang dipisahkan menurut kategori untuk memperoleh kesimpulan. Dalam konteks ini penulis mendiskripsikan secara kualitatif gambaran umum tentang pembelajaran Fikih, al Qur'an hadis, Aqidah Akhlak, SKI dan Bahasa Arab di MI Walisongo Ngaliyan.

\section{Hasil dan Pembahasan}

Pada saat penelitian dilakukan guru telah membuat Rancangan Pelaksanaan Pembelajaran sebelumnya. Materi yang diajarkan adalah pembelajaran Fiqh, al Qur'an hadis, Aqidah Akhlak, SKI dan Bahasa Arab kelas 3 MI Kurikulum KTSP. Kegiatan Rancangan Pelaksanaan Pembelajaran sengaja dibuat sama tetapi materinya berbeda.

Pada kegiatan awal guru membuka dengan salam, absensi, doa, serta penyampaian materi yang akan disampaikan. Diselingi dengan tepuk dan lagu untuk membangkitkan semangat peserta didik. Pada kegiatan inti guru menjelaskan materi kemudian menuliskan teks yang berkaitan dengan materi. 
Guru menuliskan ayat penuh dan potongan ayat beserta terjemahannya lalu guru membimbing peserta didik membaca ayat perkata kemudian peserta didik menirukan bersamasama. Setelah itu, guru meminta siswa menuliskan ayat yang dituliskan guru di papan tulis untuk disalin di bukunya masing-masing dan dikumpulkan. Guru juga memberikan kesempatan kepada peserta didik untuk maju ke depan membaca teks, dan ada yang dibaca di tempat duduk. Guru menjelaskan keterkaitan teks dengan materi kepada siswa. Pada kegiatan penutup guru dan peserta didik melakukan refleksi bersamasama dan ditutup dengan doa.

Dari hasil observasi diperoleh data bahwa pelaksanaan pembelajaran fiqh, al Qur'an hadis, Aqidah Akhlak, SKI dan Bahasa Arab kelas 3 di MI Walisongo Ngaliyan berjalan baik dan lancar, guru telah melakukan kegiatan sesuai RPP dan ada beberapa poin yang tidak dilakukan dalam kegiatan inti pembelajaran seperti memberi kesempatan siswa untuk membaca dan mengumpulkan tulisan teks. Namun, yang penulis bahas disini bukanlah kesesuaian RPP dengan pelaksanaannya. Disini penulis akan membahas mengenai problematika membaca teks Al-Qur'an dan hadis bagi siswa kelas 3 MI Walisongo Ngaliyan Semarang.

Problematika peserta didik dalam membaca teks AlQur'an dan hadis pada pembelajaran cukup bervariasi seperti pelafalan bunyi-bunyi huruf hijaiyah (makhorijul huruf), panjang pendek harakat, dan hukum bacaan (tajwid). Problematika yang ditemui di antaranya sebagai berikut:

1. Pelafalan bunyi-bunyi huruf hijaiyah (makhorijul huruf)

Peserta didik sebagian ada yang sudah bisa melafalkan bunyi huruf hijaiyah dengan benar dan ada yang masih salah, di antara kesalahan yang sering terjadi adalah sebagai berikut:
a. Huruf $ث$ dibaca w
b. Huruf $\dot{\tau}$ dibaca $ح$
c. Huruf $ذ$ dibaca $j$ 


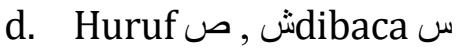
e. Antara huruf ض, ظmasih dibaca sama
f. Huruf \&dibaca ${ }^{l}$
g. Huruf قdibaca s

2. Panjang pendek

Panjang pendek dalam membaca teks Al-Qur'an dan hadis perlu diperhatikan, karena panjang pendek harakat mempengaruhi arti dan makna lafadznya. Berikut adalah kesalahan yang sering dilakukan peserta didik dalam membaca panjang pendek harakat teks Al-Qur'an dan hadis:

a. Harakat dengan panjang 2 harakat ( 1 alif) dibaca 1 harakat (setengah alif)

b. Harakat dengan panjang 4 harakat ( 2 alif) dibaca 2 harakat (1 alif)

c. Harakat dengan panjang 5-6 harakat (2,5-3 alif) dibaca 34 harakat (1,5-2 alif)

\section{Hukum bacaan (Tajwid)}

Peserta didik beberapa sudah memahami tentang hukum bacaan Al-Qur'an terutama hukum bacaan nun mati dan tanwin, hanya saja ada beberapa hukum bacaan yang masih salah dalam pembacaannya di antaranya adalah sebagai berikut:

a. Hukum bacaan mim mati

Ketika ada huruf mim mati bertemu dengan mim masih dibaca biasa, kurang dibaca dengung.

b. Hukum bacaan qolqolah

Peserta didik masih salah dalam membedakan qolqolah sugra dan qolqolah kubro. Misalnya, huruf dal di akhir ayat dibaca biasa tidak di qolqolahkan.

c. Hukum bacaan idgham bigunnah

Dengung bacaan idgham bighunnah masih kurang ada penekanan. 
d. Hukum bacaan ghunnah

Kesalahan hukum bacaan ghunnah yang terjadi hampir sama dengan hukum bacaan idgham bighunnah yaitu kurang penekanan.

Hukum bacaan huruf hijaiyah memang diwajibkan dalam membaca Al-Qur'an dan untuk hadis tidak ada kewajiban. Namun, pembiasaan membaca huruf arab sesuai dengan hukum bacaan dapat membuat kita terbiasa membaca secara fasih. Jadi, hukum bacaan huruf hijaiyah bukan hanya diterapkan pada ayat Al-Qur'an saja tetapi juga pada lafadz arab lainnya seperti hadis, nadlom, mufrodat, dan sebagainya.

Problematika yang terjadi menimbulkan berbagai permasalahan lain, akibat peserta didik memiliki kompetensi yang kurang dalam membaca, anak cenderung menjadi pemalu. Ketika membaca secara bersama-sama anak masih bisa mengikuti dengan baik dan menyuarakan dengan lantang. Akan tetapi, ketika diminta untuk membaca individu hasilnya anak membaca secara terbata-bata dan lirih.

Selain problematika membaca teks Al-Qur'an dan Hadis di atas, ada problematika lain yang terjadi pada saat pembelajaran di antaranya adalah sebagai berikut:

1. Siswa kurang fokus terhadap materi pembelajaran

Karakter peserta didik kelas 3 masih suka bermain dan tidak bisa diam, jadi ketika pembelajaran dimulai masih banyak siswa yang mengobrol sendiri, bermain dengan temannya, memperhatikan hal-hal yang tidak ada kaitannya dengan materi.

2. Guru belum menguasai materi yang disampaikan

Guru menjelaskan dengan memegang buku tes atau bahan ajar. Guru yang belum menguasai materi bisa dikarenakan kurang persiapan sehingga guru kurang memperhatikan kompetensi yang akan dicapai peserta didik dan guru melaksanakan pembelajaran hanya sebagai formalitas un- 
tuk menggugurkan kewajiban. Guru yang belum menguasai materi bisanya menyampaikan materi dengan apa adanya tanpa ada pengembangan, hal ini akan mempengaruhi kompetensi peserta didik.

3. Kurangnya variasi metode yang digunakan guru Rata-rata guru menggunakan metode ceramah, tanya jawab, dan penugasan. Hampir seluruh guru di MI Walisongo Semarang menggunakan metode tersebut sehingga peserta didik mudah bosan. Media yang digunakan guru juga kurang variatif dan kreatif, mayoritas guru menggunakan PPT sebagai media.

4. Kurangnya minat dan aktivitas siswa dalam belajar membaca Al-Qur'an dan hadis

Pembelajaran Al-Qur'an dan hadis yang menggunakan bahasa Arab kurang begitu diminati peserta didik karena kurangnya pemahaman arti dan makna teks yang dipelajari.

5. Kurangnya waktu, sarana dan prasarana baik di sekolah maupun dirumah untuk belajar siswa

Waktu yang terbatas membuat guru terbatasi dalam penggunaan media dan sarana prasarana yang ada sehingga pembelajaran kurang maksimal. Selain itu peran keluarga dalam menciptakan lingkungan belajar yang tepat juga mempengaruhi kompetensi peserta didik

6. Kurang mendukungnya lingkungan mayarakat

Selain keluarga, masyarakat juga mempengaruhi keterampilan anak.

Dari berbagai problematika di atas dapat kita ketahui bahwa problematika tersebut bisa datang dari peserta didik dan juga pendidik. Ini menjadi tugas bagi pendidik untuk meningkatkan kemampuan profesionalnya dalam rangka meningkatkan kompetensi peserta didik dalam proses pembelajaran. 


\section{Kesimpulan}

Dari pemaparan di atas dapat diketahui bahwa problematika membaca teks Al-qur'an dan hadis bagi siswa kelas 3 Madrasah Ibtidaiyah (MI) Walisongo Ngaliyan Semarang adalah

1. Problematika kompetensi peserta didik, meliputi:

a. Pelafalan bunyi-bunyi huruf hijaiyah (makhorijul huruf),

b. Panjang pendek harakat, dan

c. Hukum bacaan (tajwid).

2. Problematika dari segi lingkungan, meliputi:

a. Siswa kurang fokus terhadap materi pembelajaran,

b. Guru belum menguasai materi yang akan disampaikan,

c. Kurangnya variasi metode yang digunakan oleh guru,

d. Kurangnya minat dan aktivitas siswa dalam belajar membaca al-Qur'an,

e. Kurangnya waktu, sarana dan prasarana, baik di sekolah maupun di rumah bagi belajar siswa, dan

f. Kurang mendukungnya lingkungan masyarakat.

\section{Daftar Pustaka}

Agustina, Nora. 2018. Perkembangan Peserta Didik. Yogyakarta: Deepublish.

Bulaeng. 2016. Peningkatan Kemampuan Membaca Al-Qur'an Dengan Tartil Melalui Metode Iqra Pada Peserta Didik Kelas V Di SD Inpres Tinggimae Kecamatan Somba Opu Kabupaten Gowa. Skripsi. Fakultas Tarbiyah dan Keguruan, Universitas Islam Negeri Alauddin Makassar.

Depag RI. 1997. Metode-metode Membaca Al-Qur'an di Sekolah Umum. Jakarta: Dirjen Pembinaan Kelembagaan Agama Islam. 
Departemen Agama Republik Indonesia. 2012. Al-Qur'an dan Terjemahannya. Bandung: PT. Sinergi Pustaka Indonesia.

Jamaris, Martini. 2014. Kesulitan Belajar Perspekif, Assessment, dan Penanggulanganya Bagi Anak Usia Dini dan Usai Sekolah. Bogor: Ghalia Indonesia.

Jannah, Roichatul dan Siti Nur Kholifah. 2016. Peningkatan Keterampilan Membaca Tulisan Arab dengan Menggunakan Strategi Pembelajaran Aktif Tipe Sort Card bagi Peserta didik Kelas II MI Banu Hasyim Sidoarjo. J. PTK-PAI: Penelitian Tindakan Kelas-Pendidikan Agama Islam 7 (2).

Ramli, M. Hakikat Pendidik dan Peserta Didik. Tarbiyah Islamiyah: Jurnal: Jurnal Ilmiah Pendidikan Agama Islam 5 (1).

Saputra, M. Indra. 2015. Hakekat Pendidik dan Peserta Didik dalam Pendidikan Islam. At-Tadzkiyyah: Jurnal Pendidikan Islam 6 (2).

Tim Penulis. Metodik Khusus Pengajaran Agama Islam. Jakarta : Direktorat jenderal Pembinaan Kelembagaan Agama Islam.

Ufie, Agustinus. 2013. Kearifan Lokal (Local Wisdom) Budaya Ain Ni Ain Masyarakat Kei sebagai Sumber Belajar Sejarah Lokal untuk Memperkokoh Kohesi Sosial Siswa. Thesis. Program Studi Pendidikan Sejarah, Universitas Pendidikan Indonesia. 
THIS PAGE INTENTIONALLY LEFT BLANK 